suncracks, the latter filled with coarser sandy or silty material. Again, fine discontinuous shale laminae, often broken, occur at the bottom of the overlying arkosic sandstones ( $c f$. Sutton and Watson, text-fig. 7 (upper diagram) ). Orientated particles of shale are also found on the foresets of coarser cross-bedded units having plane bedding and low depositional dips. Interbedded associations of the coarser and finer lithologies are found. Thus some of the finely laminated beds at Diabaig with small scale grading, ripple marking, and concentrations of grit particles in ripple hollows ( $c f$. Sutton and Watson, 118) sometimes include coarser grit and sandstone bands.

These observations obviously invite comparison of the Diabaig group in Wester Ross with ordinary shallow water marine sediments, including intertidal deposits. One is not, of course, surprised to find that the older workers had considered this possibility. On page 325 of the N.W. Highland Memoir there occurs the following passage : "These facts point to shallowwater conditions, and the deposition of the sediment on a tidal shore ..."

Speculation.-What is the significance of the drastic upward change to Applecross lithology and the (apparent) lateral change in facies between Wester Ross and Skye ?

Would it not be valuable to physicists and cosmologists to know there were tides in Scotland 1,000 million years ago ? Even, perhaps (shifting the emphasis to our mother star), that the sunspot cycle was operating merrily in Wealden times?

\author{
P. Allen, \\ J. R. L. AlLLEN, \\ R. Goldring, \\ I. D. MAYCOCK.
}
Department of Geology,
UNIVERSITY, READING.
6th May, 1960.

\title{
THE OLD RED SANDSTONE OF EASTERN EKMANFJORDEN
}

SIR, - The sandstone members of the Kapp Kjeldsen and Lykta Divisions of the Old Red Sandstone described by Mr. D. L. Dineley (Geol. Mag., xcvii, 18-31), appear to contain several sedimentary features generally regarded as characteristic of turbidity current deposits, and in view of the tendency to regard most "turbidites" as of deep water, marine origin, the present examples are of more than usual interest. Whilst marine turbidites have received much attention in recent years, following the work of Kueuen and others, it is perhaps worth recalling that some of the significant early work of the mechanism of turbidity currents and the resulting deposits arose from the study of sedimentation in lakes and reservoirs (Bell, 1942). The generation of turbidity currents in quiescent bodies of water by a mechanism comparable to "flash floods" may be particularly significant in relation to the environment of the Old Red Sandstone deposits here described, the majority of which appears to be of shallow water origin.

It would, therefore, be of considerable interest if certain of the sedimentary features possibly indicative of turbidity action could be confirmed. For instance, basal conglomeratic layers are stated to occur in some sandstone layers, but it is not entirely clear whether in fact these are true graded beds. The occurrence of intra-clast conglomerates and the concentration of fossils in them suggest the action of powerful currents and concomitant rapid deposition, and again grading (both lateral and vertical) of the beds might be expected.

In the sandstones of the Lykta Division contorted bedding and sole markings are described. The former appears to have many of the features ascribed to intrastratal flowage (Rich, 1950, p. 729) but perhaps may be more correctly attributed to load casting (Kueuen, 1953, p. 1058). The sole markings described and figured (vide page 26 and text-fig. 4) certainly appear to agree closely with 
similar structures referred to as groove casts or drag marks (Kueuen, 1957, fig. 12, p. 244), and the fact that they occur only on the base of the sandstone beds would seem to argue against their being tectonic lineation.

POINTE-A-PIERRE,

K. W. BARr.

TRINIDAD, W.I.

31st March, 1960.

\section{REFERENCES}

BELL, H. S., 1942. Density Currents as agents for transporting sediments. Journ. Geol., 1, 512-537.

Kueuen, Ph. H., 1953. Features of Graded Bedding. Bull. Amer. Assoc. Petrol. Geol., xxxvii, $1044-1066$.

- 1957. Sole Markings of Graded Greywacke Beds. Journ. Geol., lxv, 231-258.

RrCH, J. L., 1950. Flow markings, groovings and intraformational crumplings as criteria for recognition of slope deposits. Bull. Amer. Assoc. Petrol. Geol., xxxiv, 717-741.

\section{REVIEW}

Beaches and Coasts. By Cuchlaine A. M. King. pp. 403 with 149 figures. Edward Arnold, London, 1959. Price 65s.

The author, an active worker on the subject, has written a comprehensive survey of our present knowledge of coastal sedimentation.

The earlier part of the book deals with the general background to the subject and includes sections on tides and wave motion (the latter at considerable length), and on methods of research, including model experiments in tanks. This is followed by an account of movement of material on the beach, which incorporates recent experimental and undersea observational work on such topics as sand ripples, longshore drift, grading and sorting, and an interesting section on the depth to which wave action is capable of disturbing sand.

Later chapters deal with beach profiles, effects of wind, the classification of beaches and coasts, coastal accretion, coastal erosion, beach gradient and profile, historical data on coastal change, and a final chapter on coastal types and developments.

Throughout, the emphasis is on underlying mechanisms and the approach is quantitative wherever this is possible. Full consideration is given to the practical problems of coastal control. The exposition is, on the whole, clear and is helped by numerous line diagrams and maps of good quality. There are no plates.

The book is a detailed survey of a rather narrow geomorphological field and will need no recommendation to those who work in that or in adjacent fields. To the large number of geologists whose interest in geomorphological work is of a general nature, parts of the book will be of minor interest only. Other parts, however, such as those dealing with experiments and measurements of sediment transport, have obvious relevance to many geological problems and will be read with profit. In addition, the book synthesises a large amount of recent work and will be welcomed by many non-specialists on that account alone.

W. W. B. 